\title{
PENGEMBANGAN PERANGKAT PEMBELAJARAN DENGAN PENDEKATAN SCIENTIFIC UNTUK MELATIH KEMAMPUAN BERPIKIR KRITIS SISWA PADA PEMBELAJARAN IPA MATERI CAHAYA KELAS IV SD
}

\author{
Koidah Fitriyah \\ Pendidikan Dasar, Pascasarjana Universitas Negeri Surabaya \\ email : fitrianoval67@yahoo.com
}

\begin{abstract}
Abstrak
Penelitian ini merupakan penelitian pengembangan yang bertujuan menghasilkan perangkat yang layak dan memenuhi kriteria : kevalidan, kepraktisan dan efektifitas perangkat pembelajaran IPA melalui pendekatan scientific untuk melatihkan kemampuana berpikir kritis siswa pada materi cahaya untuk siswa kelas IV SDN 2 Petiken Kecamatan Kedamean Kabupaten Gresik. Rancangan pengembangan dalam penelitan ini mengacu pada pengembangan perangkat model 4-D dengan bentuk rancangan one group pretest postest. Penelitian ini dilakukan di SDN 2 Petiken Kecamatan Driyorejo, Kabupaten Gresik, Provinsi Jawa Timur. Subjek dalam penelitian ini terdiri atas 35 siswa. Berdasarkan hasil analisis data secara deskriptif kualitatif, hasil validasi perangkat pembelajaran valid, keterlaksanaan pembelajaran baik $(3,9)$. Tes hasil belajar siswa dianalisis dengan $N$-Gain mengalami peningkatan yaitu sebesar 0,70 dengan kriteria "gain tinggi". Kemampuan berpikir kritis siswa juga dianalisis dengan $N$-gain mengalami peningkatan sebesar 0,63 dengan kriteria "gain tinggi", serta aktivitas siswa mengalami peningkatan. Simpulan penelitian ini, bahwa perangkat pembelajaran dengan pendekatan scientific pada pembelajaran IPA materi cahaya layak dan dapat digunakan untuk melatih kemampuan berpikir kritis siswa.
\end{abstract}

Kata Kunci: Pendekatan Scientific, Berpikir Kritis

\begin{abstract}
This study is the development research which aims to generate of tool that suitable and fulfill the criteria: the validity, practicality and effectiveness of the Learning science tool through a scientific approach to training the students' ability of Critical Thinking on light chapter in IVth Grade in SDN 2 Petiken, Driyorejo Subdistrict Gresik. Development program in this research refers to development tool and 4-D method with one group pretest posttest programs. this reseach conducted in SDN 2 Petiken, Driyorejo Subdistrict, Gresik, East Java. The subject in this research comprises of 35 students. Based on the analysis data result with qualitative descriptive, the validate result of Learning Tool is valid, the Learning process was Good (3.9). The test results of students learning were analyzed with $\mathrm{N}$-Gain has increased 0.70 With criteria "High gain". Critical thinking skill's students also analyzed with N-gain and increased 0.63 With the criteria "High gain", as well as increased the acitivity of the Students. Conclusion of this research is, that Learning Tool with scientific approach in science learning on light chapter is suitable and can be used to train the ability of Critical Thinking Students.
\end{abstract}

Keywords: Scientific approach, Critical thinking

\section{PENDAHULUAN}

Pendidikan adalah seluruh kegiatan belajar yang direncanakan dalam materi terorganisasi, dilaksanakan secara terjadwal dalam sistem pengawasan dan diberikan evaluasi berdasar pada tujuan yang telah ditentukan. Peserta didik sebagai individu membutuhkan suatu pengajaran yang sesuai dengan kebutuhan perkembangan mereka guna menjadi individu yang mampu menyelesaikan masalah di masa mendatang. Menurut UU RI No. 20 Tahun 2003 tentang Sistem Pendidikan Nasional pada pasal 1, dijelaskan bahwa pendidikan adalah usaha sadar dan terencana untuk mewujudkan suasana belajar dan proses pembelajaran agar peserta didik secara aktif mengembangkan potensi dirinya untuk memiliki kekuatan spiritual keagamaan, pengendalian diri, kepribadian, kecerdasan, akhlak mulia, sertaketerampilan yang diperlukandirinya, masyarakat, bangsa dan Negara.

Pemerintah mewujudkan usaha yang terencana tersebut melalui Kementerian Pendidikan dan Kebudayaan pada tahun 2013 
menyusun dan melaksanakan sebuah kurikulum yaitu kurikulum 2013. Kurikulum 2013 disiapkan untuk mencetak generasi yang siap di dalam menghadapi masa depan, karena itu kurikulum disusun untuk mengantisipasi perkembangan masa depan. Titik berat pada kurikulum 2013 bertujuan untuk mendorong peserta didik mampu lebih baik dalam melakukan sebuah observasi, bertanya, bernalar, dan mengkomunikasikan, apa yang mereka peroleh atau mereka ketahui setelah menerima pembelajaran. Melalui pendekatan tersebut diharapkan peserta didik kita memiliki kompetensi sikap, keterampilan, dan pengetahuan lebih baik lagi.

Sesuai Permekdikbud Nomor 81 A Tahun 2013, bahwa proses pembelajaran pada kurikulum 2013 untuk semua jenjang dilaksanakan dengan menggunakan pendekatan ilmah (scientific approach). Langkah-langkah pendekatan scientific dalam proses pembelajaran meliputi mengamati, menanya, mengkumpulkan informasi / eksperimen, mengasosiasikan/ mengolah informasi, dan mengkomunikasikan. Penerapan pendekatan scientific tersebut penting mengingat bahwa pendekatan scientific adalah proses pembelajaran yang memandu siswa untuk memecahkan masalah melalui kegiatan perencanaan yang matang, pengumpulan data yang cermat, dan analisis data yang teliti untuk menghasilkan sebuah kesimpulan (Abidin, 2014:125).

Untuk mempersiapkan diri dalam menghadapi tantangan masa depan, kemampuan berpikir kritis perlu dilatihkan kepada siswa dalam pemecahan masalah, pengambilan keputusan yang dipikirkan secara matang, dan pembelajaran tanpa henti sepanjang hayat. Salah satu fungsi sekolah adalah menyediakan tenaga kerja yang mampu dan siap dengan berbagai masalah yang ada di masyarakat, oleh karena itu, pembelajaran berpikir kritis menjadi hal yang penting untuk dimasukkan kedalam proses pembelajaran. Kondisi pembelajaran pada saat ini diharapkan diarahkan agar siswa mampu dengan banyak menanya, bukan hanya dengan menjawab saja. Pembelajaran diarahkan untuk melatih siswa berpikir analitis bukan berpikir mekanistis (rutin dengan hanya mendengarkan dan menghafal semata).
Objek yang menjadi pembelajaran dalam penataan dan penyempurnaan kurikulum 2013 menekankan pada fenomena alam, sosial, seni, dan budaya. IPA merupakan pelajaran yang berhubungan dengan fenomena alam yaitu merupakan hasil kegiatan manusia berupa pengetahuan, gagasan, dan konsep yang terorganisasi tentang alam alam sekitarnya yang diperoleh melalui serangkaian proses ilmiah. IPA juga berkaitan dengan cara mencari tahu tentang alam secara sistematik yang merupakan proses penemuan. Pembelajaran IPA memiliki fungsi yang fundamental dalam menimbulkan serta mengembangkan kemampuan berpikir kritis, kreatif, dan inovatif.

Dalam pembelajaran, guru semestinya membuat perangkat pembelajaran yang merujuk pada kegiatan menemukan untuk materi yang dipelajari. Guru dituntut untuk mampu membuat perangkat pembelajaran, menguasai kurikulum, menguasai materi, menguasai metode, dan tidak kalah pentingnya guru juga harus mampu mengelola kelas sedemikian rupa sehingga pembelajaran berlangsung aktif dan menyenangkan. Proses keterlibatan siswa secara aktif dan berjalan efektif bila pengorganisasian dan penyampaian materi sesuai dengan kesiapan siswa mental siswa dan dilengkapi dengan adanya perangkat pembelajaran yang sesuai dan memadai untuk mendukung keaktifan dan berpikir kritis siswa.

Supaya perangkat pembelajaran tersebut dapat terkonsepsi dengan baik, sehingga mampu melatih berpikir kritis siswa, maka perangkat tersebut dapat dikembangkan. Dinyatakan oleh Schaferman (1999) bahwa perencanaan pembelajaran IPA oleh guru untuk pengembangan kemampuan berpikir kritis siswa adalah suatu keharusan. Aktivitas bertanya ketika siswa berdiskusi dan bekerja dalam kelompok dapat meningkatkan kemampuan berpikir kritis (Filsaime, 2008).

Seseorang dikatakan berpikir kritis apabila mampu menunjukkan kecakapan mengidentifikasi masalah yang signifikan, menganalisis argumen, mengevaluasi dengan membandingkan kebenaran dari interpretasi, menemukan unsur-unsur yang diperlukan dalam membuat kesimpulan, memberikan penjelasan yang meyakinkan, dan membuat keputusan dari hasil yang diperoleh 
(Filsaime, 2008). Kemampuan dalam berpikir kritis dapat memicu keaktifan siswa (Fisher, 2009).

Berdasarkan observasi di kelas sasaran penelitian, diketahui bahwa siswa terlihat pasif selama kegiatan belajar mengajar berlangsung, khususnya pada materi yang dalam pembelajarannya banyak menuntut peserta didik untuk berpikir dan bernalar secara kongkrit dan abstrak. Siswa lebih suka diam dan hanya mendengarkan guru saja. Selain hal tersebut, dari hasil observasi dan diskusi diketahui bahwa dalam mengajar guru sering kali tidak mempersiapkan perangkat pembelajaran yang sesuai, bahkan terkadang tidak membuat perangkat pembelajaran, sehingga guru cenderung menggunakan teknik ceramah, siswa hanya mencatat dan mendengarkan. Selain itu hasil wawacara dengan beberapa guru ketika peneliti mengikuti acara KKG gugus, guru di beberapa sekolah menyatakan bahwa perangkat yang mereka gunakan selama ini hanya mencontoh atau menjiplak perangkat-perangkat pembelajaran yang ada di internet ataupun yang sudah jadi dalam bentuk CD. Pola pembelajaran yang masih bersifat teacher center juga sering dilakukan, sehingga keterampilan dan kemampuan berpikir kritis siswa belum dilatihkan dan dikembangkan secara maksimal. Selain itu masih adanya ketidaksesuaian antara buku guru dan buku siswa membuat guru harus mempersiapkan rencana pembelajaran lebih baik dan tepat sesuai dengan kompetensi dasar yang akan diajarkan.

Hal tersebut sejalan dengan penelitian yang dilakukan oleh Fauzi, dkk (2013). Dalam penelitiannya disimpulkan bahwa permasalahan fisika dikarenakan pengunaan metode pembelajaran yang cenderung monoton di mana guru cenderung menggunakan teknik ceramah, sehingga siswa kurang terlibat dalam menemukan suatu konsep dalam kegiatan pembelajaran ,serta pembelajaran lebih bersifat teacher center. Menurut Lavoie (dalam Yatin, 2012) pembelajaran dengan pendekatan scientific skill memiliki keuntungan yang signifikan dibandingkan dengan model pembelajaran pendekatan tradisional. Selain itu penelitian yang dilakukan oleh Krisnawati (2014) menyebutkan bahwa saat ini perangkat pembelajaran belum banyak aktivitas yang melibatkan siswa untuk berpikir tingkat tinggi.

Dalam Kurikulum 2013, pokok bahasan "cahaya" merupakan salah satu pokok bahasan yang dalam pembelajarannya banyak menuntut peserta didik untuk berpikir dan bernalar secara kongkrit dan abstrak. Kompetensi dasar untuk konsep cahaya adalah siswa dapat memahami sifat-sifat cahaya melalui pengamatan dan mendeskripsikan penerapannya dalam kehidupan sehari-hari, serta membuat suatu karya/model yang memanfaatkan sifat-sifat cahaya. Dalam topik cahaya siswa tidak hanya dituntut mempelajari teori-teori saja tetapi juga dituntut dapat melakukan pengamatan untuk menemukan konsep dan menerapkannya dalam kehidupan sehari-hari, sehingga mereka tertantang dan dengan kemampuan berpikir kritis mereka dapat menerapkan materi dalam kehidupan sehari-hari bahkan bisa menciptakan suatu karya/model yang memanfaatkan sifat-sifat cahaya, dan tidak hanya sekedar diberitahu.

Hal tersebut menjadikan dasar peneliti untuk melakukan penelitian tentang pengembangan perangkat pembelajaran khususnya mata pelajaran IPA. Berdasarkan latar belakang di atas, peneliti menentukan judul penelitian "Pengembangan Perangkat Pembelajaran dengan Pendekatan Scientific Untuk Melatih Kemampuan Berpikir Kritis Siswa Pada Pembelajaran IPA Materi Cahaya Kelas IV SD".

Permasalahan umum yang diajukan dalam penelitian ini adalah : "Bagaimana kualitas dan hasil implementasi Perangkat Pembelajaran dengan Pendekatan Scientific Untuk Melatih Kemampuan Berpikir Kritis Siswa Pada Pembelajaran IPA Materi Cahaya Kelas IV SD, yang meliputi valiidtas perangkat pembelajaran kepraktisan, keefektifan perangkat pembelajaran yang dikembangkan.

\section{METODE}

Penelitian ini merupakan penelitian pengembangan yaitu mengembangkan perangkat pembelajaran dengan pendekatan scienftific untuk melatih kemampuan berpikir kritis siswa. Perangkat pembelajaran yang dikembangkan terdiri dari Rencana Pelaksanaan Pembelajaran (RPP), Lembar Kegiatan Siswa (LKS), Buku Ajar Siswa (BAS), dan tes kemampuan berpikir kritis 
siswa, tes hasil belajar kognitif siswa yang dilengkapi dengan instrumen lembar validitas perangkat pembelajaran, lembar pengamatan keterlaksanaan RPP, lembar pengamatan aktivitas siswa selama kegiatan pembelajaran, angket respon siswa, tes kemampuan berpikir kritis siswa dan tes hasil belajar kognitif siswa serta lembar pengamatan hambatan-hambatan yang dihadapi selama kegiatan pembelajaran. Subyek dalam penelitian ini adalah perangkat pembelajaran IPA materi Cahaya, yang diuji cobakan pada siswa kelas IV SDN 2 Petiken Kec. Driyorejo, dengan jumlah siswa sebanyak 35 anak.

Rancangan pengembangan dalam penelitan ini mengacu pada pengembangan perangkat menurut Thiagarajan (1974), yang dikenal dengan model 4-D. Model ini dipilih karena sistematis dan cocok untuk megembangkan perangkat pembelajaran. Model ini terdiri dari 4 tahap, yaitu Define (pendefinisian), Design (perancangan), Develop (pengembangan), dan Disseminate (penyebaran). Penelitian ini dilakukan hanya sebatas pengembangan dan uji coba saja, maka tahap ke 4 yaitu penyebaran tidak dilakukan dengan pertimbangan perangkat ini baru didesiminasikan setelah memenuhi kelayakan.

Pada uji coba atau implementasi perangkat pembelajaran yang dikembangkan menggunakan rancangan One-Group Pretest-Posttes Design dengan rancangan sebagai berikut.

\section{$\mathrm{O}_{1} \times \mathrm{O}_{2}$}

(Tuckman, 1978)

Keterangan:

$\mathrm{O}_{1}=$ Uji awal (pre-test)

$\mathrm{X}=$ Implementasi atau pelaksanaan pembelajaran

IPA dengan pendekatan scientific

$\mathrm{O}_{2}=\mathrm{Uji}$ akhir (post-test)

Analisis data validasi perangkat pembelajaran dilakukan secara deskriptif kualitatif yang meliputi RPP, bahan ajar siswa, LKS, dan tes hasil belajar serta kemampuan bepikir kritis siswa. Deskriptif kualitatif yaitu merata-rata skor tiap komponen yang hasilnya dideskripsikan. Dalam penelitian ini batas penerimaan adalah skor rerata dari hasil penilaian para validator. Hasil skor rerata kemudian diinterpretasikan sebagai berikut.

Tabel 3.4 Nilai Kelayakan Perangkat Pembelajaran

\begin{tabular}{ll}
\hline Interval Skor & Kategori Penilaian \\
\hline$X>3,50$ & Sangat layak \\
$3,00<X \leq 3,49$ & Layak \\
$2,00<X \leq 2,99$ & Sedang \\
$1,00<X \leq 1,99$ & Kurang \\
$X \leq 1,00$ & Rendah \\
\hline
\end{tabular}

(Ngadiman, 2014)

Untuk menentukan reliabilitas instrumen pengamatan keterlaksanaan RPP, dihitung dengan menggunakan rumus Precentage of Agrement, yaitu

$$
\text { Persentage of agreement }=1-\frac{A-B}{A+B} X 100 \%
$$

Keterangan :

$\mathrm{A}=$ Frekuensi aspek tingkah laku yang teramati oleh pengamat yang memberikan frekuensi tinggi.

$\mathrm{B}=$ Frekuensi aspek tingkah laku yang teramati oleh pengamat yang memberikan frekuensi rendah

Instrumen keterlaksanaan RPP dikatakan reliable jika nilai reliabilitasnya $\geq 75 \%$ (Borich, 1994).

Sementara itu untuk penilaian keterlaksanaan RPP pada setiap fase, ditentukan dengan membandingkan rata-rata skala penilaian yang diberikan kedua pengamat dengan kriteria penilaian disajikan dalam Tabel 3.5 berikut.

Tabel 3.1 Kriteria Penilaian Keterlaksanaan RPP

\begin{tabular}{ll}
\hline Rerata & Kriteria Penilaian \\
\hline $1,00-1,49$ & Tidak baik \\
$1,50-2,49$ & Kurang baik \\
$2,50-3,49$ & Cukup baik \\
$3,50-4,00$ & Baik \\
\hline
\end{tabular}

(Diadopsi dari Rosidi, 2013)

Untuk pengamatan aktivitas siswa, llembar observasi diisi oleh pengamat dengan memperhatikana kategori yang telah ditentukan oleh penulis, yaitu melakukan prosedur yang telah ditentukan,yaitu ; a) mengamati, b) bertanya dan atau mendengarkan penjelasan guru, c) melakukan pengamatan/percobaan, d) berdiskusi dalam kelompok, e) membaca BAS,f) mengerjakan LKS, g) membuat laporan hasil 
diskusi, h) menarik kesimpulan, i) mengkomunikasikan / mempresentasikan hasil diskusi, j) aktivitas lain yang tidak relevan.

Presentase rata-rata aktivitas siswa yang diamati dapat diketahui dengan menggunakan rumus sebagai berikut.

$$
\text { Presentase aktivitas siswa }=\frac{P}{Q} \times 100 \%
$$

Keterangan :

$\mathrm{P}=$ Frekuensi aktivitas siswa yang teramati oleh pengamatan

$\mathrm{Q}=$ Jumlah aktiitas seluruh siswa selama pembelajaran berlangsung

Untuk menentukan reliabilitas instrumen pengamatan aktivitas siswa diperoleh dengan menggunakan rumus sebagai berikut.

$$
\text { Persentage of agreement }=1-\frac{A-B}{A+B} \times 100 \%
$$

$\mathrm{A}=$ Frekuensi aspek tingkah laku yang teramati oleh pengamat yang memberikan frekuensi tinggi.

$\mathrm{B}=$ Frekuensi aspek tingkah laku yang teramati oleh pengamat yang memberikan frekuensi rendah

Tes hasil belajar berupa tes pilihan ganda, isian, dan uraian untuk mengevaluasi sekaligus mengukur hasil belajar pengetahuan (kognitif). Data hasil belajar siswa diperoleh dari nilai pretest dan postest, yang diberikan pada akhir pembelajaran. Tes ini bertujuan untuk mengetahui tingkat pemahamana siswa terhadap materi yang telah diberikan, siswa dinyatakana tuntas belajar apabila mencapai > KKM yang telah ditentukan oleh sekolah. Ketuntasan belajar siswa dihitung dengan menggunakan rumus:

Ketuntasan individual

$$
=\frac{\text { Indikator yang tercapai }}{\text { Jumlah seluruh indikator }} X 100 \%
$$

Ketuntasan hasil belajar secara klaksikal dikatakan tuntas apabila $\geq 80 \%$ individu tuntas.

Ketuntasan Klaksikal

$$
=\frac{\text { Jumlah siswa tuntas }}{\text { Jumlah seluruh siswa }} \times 100 \%
$$

Skor hasil penelitian tes hasil belajar siswa dianalisis dengan menggunakan rumus.

$$
\text { Nilai }=\frac{\text { Skor yang diperoleh }}{\text { Skor maksimal }} 100 \%
$$

Tes kemampuan berpikir kritis yang digunakan untuk mengukur tingkat berpikir kritis siswa dalam bentuk uraian. Kemampuan berpikir kritis dapat diketahui melalui soal pretest dan postest. Data hasil pretest dan posttest kemampuan berpikir kritis dilakukan analisis deskriptif kualitatif menggunakan $N$-Gain. Gain menunjukkan perbedaan penguasaan atau pemahaman konsep siswa sebelum dan setelah diberikan perlakuan dilihat dari tes hasil belajarnya. Gain skor ternormalisasi menunjukkan tingkat efektifitas perlakuan daripada perolehan skor atau posttest. N-Gain dirumuskan oleh Hake (1999) sebagai berikut.

$$
\%<\mathrm{g}>=\left(\%<\mathrm{S}_{\mathrm{f}}-\mathrm{S}_{\mathrm{i}}\right) /\left(100-\%<\mathrm{S}_{\mathrm{i}}>\right)
$$

$$
\begin{aligned}
& \text { Keterangan : } \\
& <\mathrm{g}>=\text { Indeks gain (N-Gain) } \\
& \left\langle\mathrm{S}_{\mathrm{i}}>=\right.\text { Perolehan skor sebelum perlakuan } \\
& \quad(\text { pretest }) \\
& \left\langle\mathrm{S}_{\mathrm{f}}>=\right.\text { Perolehan skor setelah perlakuan } \\
& \quad \text { (postest) }
\end{aligned}
$$

Kriteria N- gain menurut Hake (1998) terbagi atas 3 tingkatan, yaitu : (1) pembelajaran dengan "gain tinggi", jika $<\mathrm{g}>\geq 0.7$; (2) pembelajaran dengan "gain sedang", jika $0.7><\mathrm{g}>$ $\geq 0.3$; (3) pembelajaran dengan "gain rendah", jika $\langle\mathrm{g}>0.3$.

Sensitifitas butir soal dihitung dengan tujuan mengevaluasi apakah butir soal yang dibuat peka terhadap efek-efek pembelajaran (sensitif).

$$
\text { Sensitivitas }=\frac{\mathrm{Ra}-\mathrm{Rb}}{\mathrm{T}}
$$

(Gronlund, 1982)

Keterangan:

$\mathrm{Ra}=\mathrm{Jumlah}$ siswa yang menjawab benar pada tes akhir

$\mathrm{Rb}=\mathrm{Jumlah}$ siswa yang menjawab benar pada tes awal 
$\mathrm{T}=$ Jumlah siswa yang mengikuti tes.

Indeks butir soal yang efektif terdapat antara 0 dan 1 , nilai positif yang lebih besar menyatakan butir soal yang lebih besar kepekaannya terhadap efek-efek pembelajaran. Butir soal yang mampu mengukur kepekaan efekefek pembelajaran adalah butir soal yang mempunyai sensitifitas $\geq 0,30$. Adapun lembar angket respon siswa dihitung dengan rumus.

$$
\frac{a}{b} \times 100 \%=c
$$

Keterangan :

$\mathrm{a}=$ Jumlah siswa tiap aspek

$\mathrm{b}=$ Jumlah seluruh siswa

c $=$ Hasil jawaban dalam bentuk persen

(Gerson dan Laurens 2003)

\section{HASIL DAN PEMBAHASAN}

Tujuan pertama penelitian ini adalah untuk menghasilkan perangkat pembelajaran dengan pendekatan scientific untuk melatih kemampuan berpikir kritis siswa pada pembelajaran IPA materi cahaya kelas IV SD yang layak, sedangkan tujuan kedua adalah untuk mengetahui kepraktisan pembelajaran dengan menggunakan perangkat pembelajaran dengan pendekatan scientific untuk melatih kemampuan berpikir kritis siswa, dan ketiga untuk mengetahui efektifitas pembelajaran. Untuk memenuhi tujuan tersebut, terlebih dahulu dilakukan penelitian pengembangan menggunakan model 4D yang dimodifikasi menjadi 3D dilanjutkan penelitian eksperimen untuk mengetahui kepraktisan dan efektifitas pembelajaran dengan pendekatan scientific untuk melatih kemampuan berpikir kritis siswa pada pembelajaran IPA materi cahaya kelas IV SD.

Secara umum semua penilaian validator terhadap perangkat pembelajaran dengan pemecahan masalah untuk melatih kemampuan berpikir kreatif siswa kelas IV SD materi pecahan adalah sebagai berikut (1) Nilai rata-rata validasi RPP dari dua validator adalah 3,61 dengan kriteria "Baik" atau menurut nilai kelayakan adalah "Sangat layak". (2) Nilai rata-rata validasi Buku Ajar Siswa sebesar 3,5 dengan kriteria "Baik" atau menurut nilai kelayakan adalah "Sangat layak" .(3) Nilai rata-rata validasi LKS menunjukan skor rata-rata penilaian LKS adalah 3,04 dengan kategori "Cukup baik" atau menurut nilai kelayakan adalah "layak". (4) Nilai rata-rata untuk tes kemampuan berpikir kritis siswa dan tes hasil belajar siswa rata-rata skor hasil penilaian dari dua validator adalah 3,28 dengan kriteria "Cukup baik" atau menurut nilai kelayakan adalah "layak"., sehingga dapat diambil kesimpulan bahwa perangkat pembelajaran berupa RPP, LKS dan tes kemampuan berpikir kritis Siswa dan hasil belajar siswa dinyatakan layak dan dapat digunakan untuk ujicoba lapangan walaupun sedikit revisi.

Keterlaksanaan Rencana Pelaksanaan Pembelajaran (RPP) yang dilakukan guru dalam kegiatan proses pembelajaran diamati dan ditulis hasil pengamatannya dalam lembar pengamatan oleh 2 orang pengamat. Hasil pengamatan terhadap keterlaksanaan RPP oleh 2 orang pengamat diperoleh rekapitulasi hasil pengamatan yang dilakukan dengan cara menghitung persentase dari jumlah aspek yang terlaksana dibagi dengan keseluruhan aspek yang diamati dikalikan $100 \%$. Keterlaksanaan Rencana Pelaksanaan Pembelajaran (RPP) yang dicapai pada uji coba pada pertemuan 1 sebesar 3,35, ratarata skor dua pengamat untuk pertemuan 2 sebesar 3,78 , dan rata-rata skor dua pengamat untuk pertemuan 3 sebesar 3,9. Skor rata-rata untuk keterlaksanaan pada tahap pendahuluan sebesar 3,8 dalam kategori "baik", tahap inti sebesar 3,6, dalam kategori "baik", tahap penutup sebesar 3,8 dalam kategori "baik", dan gambaran suasana kelas mencapai skor rata-rata 3,8, dalam kategori "baik". Adapun untuk reliabilitas pada pertemuan 1 adalah sebesar $98,6 \%$, pertemuan 2 sebesar $99,21 \%$, dan pada pertemuan 3 sebesar 98,24\%, jadi pada setiap pertemuan keterlaksanaan RPP dapat dikatakan atau masuk dalam kategori "reliabel".

Aktivitas siswa pada uji coba menunjukan bahwa frekuensi aktivitas siswa dalam pembelajaran sangat aktif. Data aktivitas siswa diperoleh melaui pengamatan selama pembelajaran dengan pendekatan scientific berlangsung. Aktivitas siswa paling dominan dalam pembelajaran pada pertemuan 1 adalah melakukan pengamatan atau percobaan yaitu sebesar $16,87 \%$, kemudian kegiatan mengamati sebesar $14,10 \%$, dan aktivitas paling rendah 
adalah aktivitas yang tidak relevan sebesar 10,26\%. Rata-rata reliabilitas aktivitas pada pertemuan 1 adalah sebesar 90,61\%. Pada pertemuan 2, aktivitas siswa paling dominan dalam pembelajaran adalah melakukan pengamatan atau percobaan yaitu sebesar $17,59 \%$, kemudian kegiatan mengamati sebesar $14,35 \%$, dan aktivitas paling rendah adalah aktivitas yang tidak relevan sebesar 5,56\%. Rata-rata reliabilitas aktivitas pada pertemuan 2 adalah sebesar $92,36 \%$. Pada pertemuan 3, aktivitas siswa paling dominan dalam pembelajaran adalah melakukan pengamatan atau percobaan yaitu sebesar $15,36 \%$, kemudian kegiatan mengamati sebesar $15 \%$, dan aktivitas paling rendah adalah aktivitas yang tidak relevan sebesar 2,50\%. Rata-rata reliabilitas aktivitas pada pertemuan 3 adalah sebesar $94,86 \%$.

Pada hasil tes belajar siswa mengalami peningkatan pada pelaksanaan postest, dengan perolehan rata-rata $N$-Gain sebesar 0,70 . Individual yang tuntas belajar pada saat pretest adalah sebanyak 2 orang, sedangkan pada saat postest meningkat menjadi 32 orang.

Pada ketuntasan klaksikal saat pretest mencapai $5,7 \%$ dan dikatakan "tidak tuntas", sedangkan saat postest ketuntasaan klaksikal mencapai $91,4 \%$ atau dinyatakan "tuntas". Sensitivitas butir soal tes hasil belajar, menunjukkan bahwa peningkatan hasil belajar merupakan pengaruh pembelajaran dengan indeks sensitivitas yaitu $0,4 \quad(\geq 0,3)$. Untuk hasil kemampuan berpikir kritis siswa mengalami peningkatan pada saat pelaksanaan postest. Peningkatan tersebut dapat diukur mengguakan $\mathrm{N}$ gain dengan rata-rata sebesar 0,63 . Perhitungan tingkat sensitivitas setiap butir soal tes kemampuan berpikir kritis menunjukkan bahwa peningkatan hasil kemampuan berpikir kritis merupakan pengaruh pembelajaran dengan indeks sensitivitas yaitu $0,44(\geq 0,3)$.

Setelah dilakukan pengamatan terhadap keterlaksanaan pembelajaran, dilakukan pula pengukuran respon siswa berupa angket terhadap penerapan pembelajaran yang telah dikembangkan. Dilakukan penyebaran angket untuk mengetahui respon siswa terhadap pembelajaran yang telah dilaksanakan. Hasil analisis persentase respon siswa menunjukkan respon positif terhadap perangkat dan pembelajaran dengan pendekatan Scientific.

\section{HASIL PENELITIAN}

Berdasarkan analisis hasil penelitian perangkat pembelajaran dan analisis hasil ujicoba perangkat pembelajaran dengan pendekatan scientific pada pembelajaran IPA materi cahaya yang telah dilakukan, maka dilakukan pembahasan. Pembahasan hasil ujicoba yang dilakukan meliputi pengembangan perangkat pembelajaran IPA dengan pendekatan scientific dalam melatikan keterampilan berpikir kritis yang terdiri atas, validitas, kepraktisan, keefektifan perangkat yang meliputi : validasi RPP, bahan ajar siswa, LKS, lembar penilaian, keterlaksanaan pembelajaran (RPP), aktivitas siswa, kendala yang dialami selama pembelajaran, hasil belajar siswa dan respon siswa setelah melaksanakan pembelajaran. Rencana Pelaksanaan Pembelajaran (RPP) mengacu pada kurikulum 2013 yang menerapkan pendekatan scientific untuk melatih berpikir kritis. Menurut Mulyasa (2013), siswa dilatih untuk mampu berpikir logis, runut, dan sistematis, dengan menggunakan kapasitas berpikir tingkat tinggi. RPP ini terdiri dari tiga kali pertemuan pada materi cahaya yang di dalamnya dijelaskan secara rinci sesuai tahapan dalam pendekatan scientific.

Kelayakan RPP sesuai dengan isinya, meliputi aspek validitas konstruksi, isi, kegiatan pembelajaran, serta sumber dan alat pembelajaran, dapat terlihat bahwa rata-rata skor validasi perangkat RPP yang diperoleh adalah 3,61 dengan kriteria "Baik", sehingga RPP dinyatakan sangat layak sesuai dengan kriteria kelayakan yang diterapkan oleh Ngadiman (2014) yang artinya RPP tersebut telah tersetruktur sesuai ketentuan RPP. Hal ini sesuai dengan BSNP (2007), bahwa menyusun RPP secara lengkap dan sistematis agar pembelajaran berlangsung secara interaktif, inspiratif, menyenangkan, menantang, memotivasi peserta didik untuk berpartisipasi aktif, serta memberikan ruang cukup bagi prakarsa, kreativitas, dan kemandirian sesuai bakat, minat, dan perkembangan fisik serta psikologs peserta didik. Bahan ajar siswa yang digunakan dalam penelitian ini berisi uraian pembelajaran yang digunakan oleh siswa sebagai panduan atau sumber belajar baik selama kegiatan pembelajaran 
berlangsung maupun digunakan secara mandiri. Bahan ajar yang dikembangkan mencakup pokok bahasan cahaya dengan sub bahasan sifat-sifat cahaya, penerapan sifat cahaya pada alat optik, dan karya sederhana yang menerapkan sifat-sifat cahaya. Validasi materi ajar yang dilakukan oleh validator menunjukkan bahwa hasil validasi dari para pakar mendapatkan skor rata-rata 3,5 dengan kriteria "Baik" bahan ajar tersebut sangat layak untuk diterapkan sesuai dengan kriteria kelayakan yang diterapkan oleh Ngadiman (2014).

Lembar kerja siswa dibagi menjadi tiga kali pertemuan,dengan masing-masing pertemuan satu LKS. Validasi LKS dilakukan oleh validator menunjukkan bahwa hasil validasi yang meliputi aspek syarat didaktik, kelayakan konten LKS, prosedur, dan pertanyaan mendapatkan skor ratarata 3,04 dengan kriteria penilaian "cukup baik", sehingga LKS dinyatakan layak sesuai dengan kriteria kelayakan yang diterapkan oleh Ngadiman (2014) , yang artinya LKS tersebut cukup baik digunakan sebagai sarana untuk berinteraksi antar siswa dalam memecahkan masalah sesuai dengan pendekatan scientific untuk melatih berpikir kritis siswa. Hal ini sesuai dengan pendapat Nur (2008) bahwa LKS yang baik adalah yang memiliki ciri yaitu; membantu siswa menemukan konsep, membantu siswa menerapkan dan mengintegrasikan berbagai konsep yang telah ditemukan, penuntun belajar, sebagai penguatan, dan sebagai petunjuk praktikum, sehingga pengalaman belajar siswa lebih bermakna.

Tes hasil belajar digunakan untuk mengukur hasil belajar kognitif siswa setelah menerapkan perangkat pembelajaran yang dikembangkan. Tes yang dikembangkan dalam bentuk pilihan ganda 10 butir soal, 5 soal isian, dan 3 soal uraian. Tes hasil belajar dilengkapi dengan kisi-kisi yang disusun mengacu pada taksonomi Bloom. Hasil dari validator untuk validasi tes hasil belajar mendapatkan skor ratarata 3,28 dengan kategori penilaian "cukup baik", sehingga THB dinyatakan layak sesuai dengan kriteria kelayakan yang diterapkan oleh Ngadiman (2014) dan revisi kecil . Hal tersebut menunjukkan tes hasil belajar yang dikembangkan layak diterapkan di sekolah, yang artinya tes hasil belajar sudah memenuhi standart penilaian. Hal ini sudah sesuai dengan standart BSNP (2006) bahwa standart umum penilaian sesuai dengan prinsip-prinsip penilaian yang salah satunya informasi dihimpun mencakup ranah-ranah yang sesuai dengan standart isi dan standart kompetensi kelulusan.

Dari data yang telah diperoleh saat pelaksanaan pembelajaran, dapat dikemukakan bahwa rata-rata skor pada pertemuan pertama relatif lebih rendah daripada pertemuan kedua dan ketiga. Pada pertemuan pertama terdapat beberapa aspek yang cukup banyak aspek yang masih dalam kategori cukup, yaitu pada aspek guru dalam menyampaikan konsep, menjelaskan prosedur observasi, membimbing siswa melakukan pengamatan, membuat pertanyaan, dan membimbing siswa dalam hal menalar, sehingga hal ini berdampak pada aspek lain. Pada aspek suasana kelas didapatkan hasil rata-rata "Baik". Mengelola KBM dan suasana belajar dengan baik sesuai dengan pendapat Djamarah (2002) bahwa dalam melaksanakan tugasnya sebagai guru mampu mengatur siswa dan sarana pengajaran serta mengendalikan suasana yang menyenangkan untuk mencapai tujuan pengajaran. Rata-rata hasil pengamatan keterlaksanaan pembelajaran secara keseluruhan termasuk dalam kategori "Baik". Hasil reliabilitas instrumen keterlaksanaan pembelajaran secara berturut-turut sebesar 98,32\%; 99,21\%; 98,45\%, sehingga rata-rata reliabilitas RPP secara keseluruhan adalah $98,66 \%$. Nilai koefisien reliabilitas instrumen keterlaksanaan pembelajaran yang diperoleh lebih dari 0,75 atau 75\%. Menurut Borich (1994) instrumen dinyatakan baik dan dapat digunakan jika reliabilitasnya lebih dari sama dengan 0,75 atau $75 \%$. Dengan demikian instrumen keterlaksanaan pembelajaran dapat dinyatakan sebagai instrumen berkategori baik dalam mengukur keterlaksanaan RPP selama pembelajaran.

Hasil belajar siswa diperoleh dari tes hasil belajar siswa yang dilakukan sebanyak dua kali, yaitu tes awal (pretest) untuk mengetahui kemampuan awal siswa sebelum diberikan perlakuan dan tes akhir (postest) untuk mengetahui pemahaman konsep siswa setelah diberikan perlakuan dengan menggunakan pendekatan scientific pada materi cahaya. Ketuntasan hasil belajar diukur berdasarkan indikator dan tujuan pembelajaran yang dikembangkan. Peneliti mengukur serta 
membandingkan ketuntasan belajar berdasarkan nilai yang diperoleh saat pretest dan postest. Ketetapan Kriteria Ketuntasan Minimal (KKM) untuk mata pelajaran IPA di SDN 2 Petiken adalah $\geq 70$. Hasil yang telah diperoleh dapat dikemukakan bahwa pelaksanaan pretest dengan objek penelitian 35 siswa, hanya ada dua siswa yang tuntas belajar dalam pelaksanaan pretest. Pada pelaksanaan postest dari 35 siswa yang mengikuti tes, semua siswa dapat mencapai KKM IPA, maka kelas tersebut dikatakan tuntas secara klaksikal.

Pada saat pelaksanaan pretest hanya ada dua siswa yang tuntas, hal ini disebabkan siswa belum mendapatkan pendalaman mengenai materi cahaya, sehingga mereka hanya mampu mengerjakan berdasarkan pengetahuan awal yang mereka miliki. Hal tersebut berbeda pada pelaksanaan posttest, di mana siswa telah mendapatkan materi mengenai cahaya secara mendalam, sehingga semua siswa bisa tuntas belajar. Sejalan dengan penelitian yang dilakukan oleh Yuniarti,dkk (2004) yang menyebutkan bahwa melalui pembelajaran aktif, peserta didik diajak untuk turut serta dalam semua proses pembelajaran, baik mental maupun fisik, maka peserta didik akan merasakan suasana yang lebih menyenangkan dan memperoleh pembelajaran yang bermakna, sehingga prestasi belajar dapat dimaksimalkan. Kondisi seperti ini tampak pada hasil belajar yang menunjukkan adanya peningkatan hasil belajar siswa, hal ini sesuai dengan pengukuran tingkat indeks sensitivitas tiap butir soal yang menunjukkan bahwa indeks sensitivitas pada soal yang dikembangkan secara rata-rata 0,4 . Ini menunjukkan bahwa butir soal tersebut memiliki kepekaan yang cukup terhadap efek pembelajaran yang diberikan, sesuai dengan pernyataan Grondlund (1982), jika indeks butir soalmempunyai sensitivitas yang tinggi $(\geq 0,30)$, maka mempunyai efek kepekaan terhadap pembelajaran.

Kemampuan siswa dalam menerima materi (penguasaan konsep) dapat dianalisis dengan menggunakan Gain Score yang ternormalisasi $(N$ Gain). Hasil N-Gain pada Tabel 4.10 halaman 98 menunjukkan bahwa hampir seluruh siswa memiliki rata-rata skor gain yang tinggi yaitu 0,70 $(\geq 0,30)$, ini berarti kemampuan penguasaan konsep yang diberikan melalui pendekatan scientific tinggi. Hal ini sesuai dengan Hake (1999), bahwa Gain skor ternormalisasi yang tinggi menunjukkan tingkat efektifitas.

Pada penelitian ini ingin mengetahui apakah pembelajaran menggunakan pendekatan scientific dapat melatihkan keterampilan berpikir kritis siswa. Hal ini sejalan dengan Depdiknas (2003) yang menyatakan bahwa salah satu kecakapan hidup (life skills) yang perlu dikembangkan melalui proses pendidikan, adalah keterampilan berpikir. Sesuai dengan pernyataan Williams , dkk (2004) yang menyatakan bahwa berpikir kritis penting diterapkan di kelas, karena keterampilan berpikir kritis dapat dilatih pada siswa melalui pendidikan berpikir, yaitu melalui belajar menalar, di mana proses berpikir diperlukan keterlibatan aktivitas si pemikir itu sendiri. Berpikir kritis adalah orientsi teoritis penting yang berfungsi membantu motivasi belajar siswa dalam proses belajar mengajar (Phan, 2010). Kemampuan berpikir kritis yang diamati dalam peneitian ini adalah kemampuan untuk mengenal masalah, memberikan penjelasan lebih lanjut, menerangkan sebab, membuat sekuen/urutan, dan dapat menarik kesimpulan.

Pada awal pertemuan siswa mengerjakan soal pretest kemampuan berpikir kritis, hasilnya cukup mengejutkan, semua siswa menunjukkan bahwa siswa belum mampu untuk berpikir kritis, siswa masih kesulitan menjawab soal-soal tersebut. Pada pertemuan pertama pembelajaran, siswa belum terbiasa berpikir kritis lebih terlihat, siswa banyak yang bertanya dan memerlukan bimbingan.

Berdasarkan hasil analisis berpikir kritis didapatkan peningkatan kemampuan berpikir kritis siswa yang diukur dengan menggunakan $\mathrm{N}$ Gain sehingga diperoleh skor rata-rata 0,63 , yang artinya siswa mengalami peningkatan kemampuan berpikir kritis setelah pembelajaran berlangsung. Selain itu juga diperoleh rerata skor saat pretest sebesar 47,0 dan mengalami peningkatan pada saat postest yaitu diperoleh rerata skor 80,3. Peningkatan ini disebabkan adanya penerapan pendekatan scientific dalam pembelajaran yang dilatih kepada siswa untuk merangsang kemampuan berpikir kritis siswa selama proses pembelajaran berlangsung.

Dalam pendekatan scientific terdapat langkah menanya, langkah ini sangat penting 
dalam memacu kemampuan berpikir kritis siswa. Hal ini sesuai dengan Filsaime 2008), bahwa poroses pembentukan berpikir kritis kepada siswa tidak timbul secara kebetulan tetapi memerlukan persiapan, seperti kemampuan berpikir dapat melalui bertanya kritis. Senada dengan pendapat Browne \& Keeley (2012) bahwa kemampuan berpikir kritis meliputi pengetahuan untuk membuat serangkaian pertanyaan kritis yang saling bertautan dan menjawab pertanyaanpertanyaan tersebut pada saat yang tepat. Kegiatan bertanya untuk melatih berpikir logis, runut, dan sistematis, dengan menggunakan kapasitas berikir tingkat tinggi dapat dilatihkan dengan menggunakan pendekatan scientific, karena pada pendekatan scientific melatihkan kegiatan mengamati, menanya, menalar, mencoba, dan mengkomunikasikan sehingga siswa akan terlatih berpikir kritis.

Berdasarkan hasil pengamatan aktivitas siswa, aktivitas terendah adalah aspek perilaku tidak relevan, hal ini menunjukkan bahwa siswa memilih aktif dalam mengikuti kegiatan belajar mengajar. Hal ini sesuai dengan Slameto (2010), dalam proses belajar mengajar guru perlu menimbulkan aktivitas pada siswa dalam berpikir maupun berbuat, dengan demikiana pengetahuan yang diberikan tidak berlalu begitu saja. Selain itu pembelajaran akan bermakna dan efektif apabila siswa secara aktif berkontribusi di dalamnya. Hal ini sesuai dengan Pribadi (dalam Krisnawati 2014), bahwa proses belajar mengajar akan berlangsung efektif jika siswa terlibat secara aktif dalam tugas-tugas yang efektif dan berinteraksi dengan materi pelajaran secara intensif. Sejalan dengan pendapat tersebut Fisher (2009) menyatakan bahwa kemampuan dalam berpikir kritis dapat memicu keaktifan siswa.

Berdasarkan pengamatan aktivitas siswa dapat diketahui bahwa reliabilitas dari masingmasing aspek aktivitas siswa memiliki nilai lebih besar dari 0,75 atau 75\%. Menurut Borich (1994) hasil pengamatan yang memiliki nilai reliabilitas lebih besar atau sama dengan 0,75 atau $75 \%$ dikatakan reliable. Hasil ini dapat mengindikasikan bahwa hasil pengamatan yang dilakukan oleh kedua pengamat tersebut mendekati dengan keadaan yang terjadi pada saat pembelajaran berlangsung. Kendala yang harus dihadapi selama pembelajaran yaitu pada saat pertemuan pertama waktu yang dibutuhkan lebih lama dari yang disediakan karena belum terbiasa dengan langkah-langkah pembelajaran scientific.Terutama pada saat kegiatan menanya, siswa masih kesulitan merumuskan masalah atas apa yang mereka amati. Tetapi pada pertemuan selanjutnya dengan bimbingan guru siswa sudah mulai terbiasa.

Dari hasil penelitian, siswa memberikan respon yang tinggi terhadap ketertarikan, keterbaharuan, kejelasan komponen pembelajaran. Selain itu siswa merasa senang dengan pembelajaran dengan menggunakan pendekatan scientific, siswa juga setuju jika materi berikutnya diajarkan dengan menggunakan pendekatan scientific. Hal itu terlihat dari hasil respon siswa terhadap perasaan ketika mengikuti pembelajaran 90\% siswa merasa senang, terhadap komponen pembelajaran presentase rata-rata $85,71 \%$ siswa merasa tertarik dengan komponen pembelajaran, $82,9 \%$ siswa menyatakan bahwa komponen pembelajaran baru, hal ini selaras dengan penelitian yang dilakukan oleh Krisnawati (2014) menyebutkan bahwa saat ini perangkat pembelajaran belum banyak aktivitas yang melibatkan siswa untuk berpikir tingkat tinggi, dan $85 \%$ siswa menyatakan komponen pembelajaran jelas dan mudah dipahami. Respon siswa sebanyak $90 \%$ setuju jika materi pembelajaran berikutnya menggunakan pembelajaran scientific, dan $80 \%$ menyatakan setuju jika mata pelajaran lain juga menggunakan pendekatan scientific.

\section{PENUTUP}

Berdasarkan hasil uji coba perangkat, analisis, diskusi, pembahasan, dan kendalakendala yang dihadapai dalam proses pembelajaran, maka secara umum dapat disimpulkan bahwa : Validasi perangkat pembelajaran dengan pendekatan scientific untuk melatih kemampuan berpikir kritis siswa meliputi validasi RPP, LKS, BAS, dan lembar penilaian dengan nilai validasi rata-rata berkategori bagus, layak digunakan dan valid. (2) Keterlaksanaan rencana pembelajaran yang menggunakan pendekatan scientific untuk melatih kemampuan berpikir kritis siswa yang meliputi mengamati, menanya, melakukan percobaan, mengasosiasi/menyimpulkan, megkomunikasikan 
menunjukkan kategori baik. (3) Aktivitas siswa selama pembelajaran berlangsung menunjukkan keaktifan siswa yang melakukan pengamatan, melakukan percobaan, dan mendiskusikan tugas, sedangkan perilaku tidak relevan memperoleh skor terendah pada setiap pertemuan. (4) Hasil tes kemampuan berpikir kritis siswa menunjukkan peningkatan yang signifikan dari hasil pretest, dan hasil belajar kognitif atau pengetahuan siswa secara keseluruhan juga memuaskan. (5) Siswa merespon baik terhadap komponen pembelajaran yang menggunakan pendekatan scientific untuk melatih kemampuan berpikir kritis siswa.

Dari uraian di atas dapat diambil kesimpulan bahwa perangkat pembelajaran IPA dengan pendekatan scientific yang dikembangkan telah valid, praktis, dan efektif untuk melatihkan kemampuan berpikir kritis siswa.

Berdasarkan penelitian yang telah dilakukan, peneliti memberi saran-saran sebagai berikut : (1) Penelitian yang telah dilakukan dengan mengembangkan perangkat pembelajaran IPA dengan pendekatan scientific untuk melatihkan kemampuan berpikir kritis siswa. Berdasarkan hasil tersebut peneliti memberikan saran untuk lebih memberikan latihan-latihan kemampuan berpikir kritis siswa untuk mencetak generasi yang siap di dalam menghadapi masa depan. (2) Penelitian yang telah dilakukan dengan mengembangkan perangkat pembelajaran IPA materi bunyi dapat digunakan sebagai alternatif untuk melatih kemampuan berpikir kritis siswa pada materi IPA lainnya.

\section{DAFTAR PUSTAKA}

Abidin, Yunus. (2014). Desain Sistem Pembelajaran Dalam Konteks Kurikulum 2013. Bandung: PT. Refika Aditama.

Borich.(1994). Observation skills for effective teaching. United States of America: Macmillan Publishing Company.

Browne, M.N, \& Keeley, S.M. (2012). Pemikiran kritis: panduan untuk mengajukan dan menjawab pertanyaan kritis. New Jersey: Indeks.

Depdiknas.(2003). Undang-Undang RI Nomor 20 Tahun 2003, tentang Sistem Pendidikan Nasional.

Djamarah, Syaiful Bahri.(2002). Psikologi Belajar. Jakarta:PT. Rineka Cipta.
Fauziah, R., Abdullah, A.G, \& Hakim, D.L. (2013). Pembelajaran saintifik elektronika dasar berorientasi pembelajaran berbasis masalah. INVOTEC, Vol. IX, No.2, 165178.

Filsaime, Dennis K. (2008). Menguak Rahasia Berpikir Kritis Dan Kreatif. Jakarta: Prestasi Pustakarya

Fisher, Alec. (2009). Berpikir Kritis Sebuah Pengantar. Jakarta:Erlangga.

Gronlund, N.E. (1977). Constructing achievement test, second edition. London: Prentice-Hall Inc.

Hake, R.R. (1999). Analyzing change (online), (http:// www.Physics. indiana.edu/sdi/Analyzing change gain.pdf, diakses tanggal 1 maret 2015.

Kemendikbud.(2013).Implementasi Kurikulum 2013. Jakarta: Kementerian Pendidikan dan Kebudayaan.

Krisnawati, N.M. (2014). Pengembangan Perangkat Pembelajaran Biologi Model Kooperatif Dengan Pendekatan Scientific Untuk Melatih Berpikir Kritis Siswa SMA (Tesis magister pendidikan tidak dipublikasikan). Universitas Negeri Surabaya.

Mulyasa, E. (2006). Kurikulum Tingkat Satuan Pendidikan. Bandung :PT. Remaja Rosdakarya

Mulyasa, E. (2013). Pengembangan dan Implementasi Kurikulum 2013. Bandung : PT. Remaja Rosdakarya

Ngadiman.(2014). "Pengembangan Perangkat Pembelajaran Menggunakan Pendekatan Scientific Untuk Meningkatkan Hasil Belajar dan Melatihkan Keterampilan Berpikir Kritis Siswa (Tesis Magister Pendidikan). Surabaya :Universitas Negeri Surabaya.

Nur, M. (1998). "Pengembangan Perangkat Pembelajaran dalam Rangka Menunjang Implementasi Kurikulum IPA 1994 di Indonesia". Makalah disajikan pada Improving Teaching Proficiency of Indonesian Yunior and Senior Secondaryb Science Teacher di SEAMEO-ReCSAM, Penang, Malaysia tanggal 14-18 maret 1998 
Phan, H.P. (2010). Crtical thinking as a selfregulatory process component in teaching and learning. Psichotema. Vol. 22, No.2, 284-292.

Schafersman, S.D. (2012). An Introducing to Critical Thinking. Dalam www.wikipedia.2 Nopember.

Slameto.(2010). Belajar dan Faktor-Faktor yang Mempengaruhi. Jakarta: Rineka Cipta.

Tiagarajan, S., Semmel, D.S, \& Semmel, M.I. (1974). Instructional Development for Training Teachers of Exceptional Children. Bloomington Indiana: Indiana University.

Williams. (2004). "Teacing to Thir Thinking: A Strategy to Meet the Critical-Thinking Needs Gifted Student". Journal Of The Education Of The Gifted. Vol 28, No.1, PP 56-79

Yatin, M., Siti, H., Enni, S., Priyantini, W. (2012). Pengembangan Perangkat Pembelajaran dengan Pendekatan scientific skill teknologi fermentasi berbasis masalah lingkungan. Jurnal Ilmu Kependidikan, 41(1): $21-26$

Yuniarti, Riyadi, Sri Subanti. (2014). "Pengembangan Perangkat Pembelajaran BerbasisMasalah (PBL) dengan Pendekatan Ilmiah (Scientific Approavh) Pada Materi Segitiga Kelas VII SMP SEKabupaten Karanganyar Tahun Pelajaran 2013/2014)". Jurnal Elektronik Pembelajaran Matematika .Vol.2 No.9, hal.911-921 